\title{
Repercussions of Improved Municipal Solid Waste Management on Flood Risk Reduction: The Case of Dar es Salaam, Tanzania
}

\author{
Tumpale Sakijege \\ Department of Urban and Regional Planning, School of Spatial Planning and Social Sciences, Ardhi University, Dar es Salaam, \\ Tanzania \\ Email: tumpaleg@gmail.com
}

How to cite this paper: Sakijege, T. (2019). Repercussions of Improved Municipal Solid Waste Management on Flood Risk Reduction: The Case of Dar es Salaam, Tanzania. Journal of Geoscience and Environment Protection, 7, 177-199.

https://doi.org/10.4236/gep.2019.79013

Received: August 12, 2019

Accepted: September 23, 2019

Published: September 26, 2019

Copyright $\odot 2019$ by author(s) and Scientific Research Publishing Inc. This work is licensed under the Creative Commons Attribution International License (CC BY 4.0).

http://creativecommons.org/licenses/by/4.0/

\begin{abstract}
Indisputably, flooding is one of the predicaments that have plagued many countries throughout the world. Consequently, Improvement of Municipal Solid Waste Management-(MSWM) has recently become one of the ways that is believed to help in reducing the impact of flooding. Following the fact that Dar es Salaam, the commercial capital, has nearly 5 million inhabitants and several of the wards are in flood-prone areas, the City authorities introduced new models of MSWM by incorporating public-private partnership as a deliberate action envisioned to improve MSWM. Nevertheless, the extent to which the strategy is effective in minimizing flood risks had not been adequately researched, which prompted a need to conduct a study. Specifically, the study sought to: assess the current practice of SWM in the settlement; examine the extent to which flood risk had been reduced given the application of the new models of SWM. This is primarily a case study which used Keko Machungwa in Dar es Salaam as the study area. Different forms of data collections tools were used for instance interviews of households and officials, photographs, spatial data etc. The findings indicated that Jukwaa la Wanawake in Keko Machungwa, a newly emerged community-driven organization was doing a fairly good job in handling SWM. This social entity was capable of collecting 40 tons of solid wastes per week and arranged for transportation. Overall, there was a marked decrease in haphazard dumping within the settlement. Despite the improvement, however, flooding was still persistent and was an alarming challenge. To that effect, this study recommends that improving solid waste collection could help overcome the problem of flooding particularly if integrated with other initiatives which include 1) Investment in robust flood control structures; 2) Adherence to Urban planning and disaster management policies which prohibit development in hazardous areas, an in-
\end{abstract}


stance of which being demolishing the existing building structures located in the water way in Keko Machungwa and; 3) Initiate large scale flood risk reduction settlement schemes.

\section{Keywords}

Municipal Solid Waste, Flood Risk, Collection Points, Jukwaa la Wanawake (Women Participatory Group)

\section{Introduction}

\subsection{Municipal Solid Waste Management}

In many developing countries, urbanization has compelled people to move to the vicinity of the cities. Tragically, although these areas in most instances have enough space for housing, they were not planned, which has resulted in the growth of informal settlements. This challenge has in the worst case scenario been amplified by the lack of good social services such as municipal solid waste management (MSWM). It is at this juncture that the aspect of MSWM in urban areas has moved into the centre of scholarly discourses.

To begin with, in other countries the relationship between generated and collected Municipal Solid Waste (MSW) has been extensively studied (Babalola et al., 2010; Lohri et al., 2014; Kasala, 2014; Kouloughli \& Kanfoud, 2017; Yukalang et al., 2018). Similarly, it is believed that nearly $100 \%$ of the MSW generated in developed countries is being collected because of the prevalence of proper Management and financial capacity (Kaza et al., 2018). On the contrary, a bulk of literature has inclined towards advancing that MSWM in developing countries has been and will continue to be problematic since many governments are not able to meet all the needs of the rapidly growing population (Memon, 2010; Kasala, 2014; Kaza et al., 2018).

Globally, the doctrine of MSW has drastically been enforced. Attesting to that, Kaza et al. (2018) note that 3.40 billion tons of solid waste is expected to be generated by 2050 and in developing countries MSW will triple. This is attributed to the rapid increase of the number of people and development, causing MSWM to be amongst the biggest challenges worldwide. In 2018, for example, already 55.3 percent of the world's population was estimated to be living in urban settlements. By 2030, urban areas are projected to house 60 percent of people globally (UN, 2018). Invariably, this population growth has persistently been hampering MSWM especially in developing countries. Therefore, it can rightly be foreseen that the world will witness a rapid increase of MSW in the near future, making the collection of all waste more and more difficult if countries will not have ambitious plans to manage it (Kaza et al., 2018).

Moreover, as countries develop, more solid wastes (SW) are generated ${ }^{1}$; how-

${ }^{1}$ Not necessarily for developed countries, notably in Switzerland more than 30 years ago even small communities around Genève had small bins for organic waste, paper, plastic and glass. 
ever, SW will not cause problem to the communities if there are strategies to make good use of solid waste (e.g. recycling). Taking an example from Tanzania, the country aims to transform the nation into a middle income country by 2025 . It follows logically, therefore, that once the set target has been achieved, the country will most likely experience mushrooming of people in the cities, which will lead to a tremendous increase in MSW.

By and large, while developing countries have been using a small amount of their budget for MSWM, their counterparts' developing countries spend more than $30 \%$. However, despite the use of a large amount of budget for SWM, yet the amount of the waste collected does not reach 50 percent of the MSW produced, which is counterproductive (Memon, 2010; Kasala, 2014; Kaza et al., 2018).

The major sources of MSW include: Residential (home), commercial and industries/institutions. Nagabooshnam (2011) and Okot-Okumu (2012) reported that households are known to be one of the biggest contributors of MSW. The waste generated by households is more than $50 \%$. Additionally, up to $30 \%$ of the MSW originate from commercial activities, while less than $10 \%$ are contributed by other sources like industries and institutions, among others. Deducing from this argumentation, it is evident that unplanned areas (which accommodate majority of urban dwellers) in developing countries suffer the consequences of poor MSWM because of the nature of the settlement they live in. The overall spatial features of most unplanned settlements are characterized by haphazard housing development, poor solid waste disposal and narrow streets (non existence in most settlements) which are not accessible by motor vehicles, thereby causing myriads of complexities during the MSW collection (Sakijege et al., 2012; Rasmussen, 2013).

In the absence of proper MSWM especially in developing countries, many people have resorted to: burning, dumping on rivers and open spaces. There are many side effects that result from poor disposal of as well as haphazard dumping of MSW. These include, inter alia, communicable diseases (Babalola et al., 2010; Andrianisa et al., 2016; Zohoori \& Ghani, 2017) environmental pollution (Kasala, 2014) and blockage of drainage channels to the extent of causing flooding (Sakijege et al., 2014).

Following the persistent and notable challenge of MSWM in Tanzania, a number of responsive initiatives have been made with a view to minimizing the side effects resulting from poor management. One such initiative is the Public-Private Partnership (PPP) (Lohri et al., 2014 in Zhu et al., 2007; Abdrabo, 2008) which has been identified as a viable means to effectively addressing constraints of financing ${ }^{2}$, management and maintenance of public goods and services (Lohri et al., 2014). It is envisioned that PPP would lead to increased efficiency in the delivery of services. Many governments in developing countries opted to engage private companies in order to improve the efficiency in MSWM.

\footnotetext{
${ }^{2}$ The initiative was specifically for Ethiopia, however, could be a model for Tanzania.
} 
The empirical literature available confirms that poor MSWM is a threat to flood control initiatives as uncollected wastes usually block drainage channels, leading to recurrent flooding (Gupta, 2007 as cited in Lamond et al., 2012; Mercycorps, 2011; Boadi \& Kuitunen, 2003).

The paper is structured as follows: in the first place, a snapshot on the research background, rationale and objective of the study is provided. This done, the second part discuss drainage systems blockage in urban areas and the responses to overcome flood globally, in Asia and finally in the African countries. This section is followed by theoretical stances that were deemed relevant for informing the study (Section 3). The next section (Section 4) describes the materials and methods used in data collection, processing and analysis. The section is followed by yet another one that presents and discusses the findings (Section 5) and discussion (Section 6). Finally, the last section provides the conclusions and policy implications emanating from the study findings.

\subsection{Rationale and Objective of the Study}

The motivation to undertake the study was premised on a number of factors. In the first place, as the reviewed literature has already established, Tanzania is among the countries that employed the model of public-private sector in MSWM. The private entities have been used to complement the inadequate capacity of the public sector. However, the extent to which the efforts made to implement the SWM has not appraised through scientific investigations. Secondly, increased flood impact has been reported by many scholars (Sakijege et al., 2012; Agbola et al., 2012; Salami et al., 2017). Moreover, studies on SWM especially in Dar es Salaam (the former capital City of Tanzania), focused on the challenges faced in Solid Waste Management initiatives (Bubegwa, 2012; Kasala, 2014), households perspectives on solid waste collection by the private sector (Kassim \& Ali, 2006) and potential and constraints of composting domestic solid waste in developing countries (Mbuligwe et al., 2002).

Notably, none of the cited studies examined how improved MSWM contributes to flood risk reduction. Thus, there is a dearth of knowledge on the relationship between improved MSWM and flood risk reduction. This paper aimed to bridge the aforementioned research gap by assessing the current practice of solid waste management in the settlement; examine the extent to which flood risk had been reduced given the application of the new models of MSWM and finally recommend on how flood risk could be reduced.

\section{Drainage Systems Blockage in Urban Areas and the Responses to Overcome Flood}

One of the items that have been highly advocated by different writers is the relationship between flooding and blockage of drainage channel resulting from poor MSWM. This subsection provides a review of the literature delineating the responses that have been made to overcome the drainage systems blockage caused 
by uncollected and poor disposal of MSW, especially in urban areas. Furthermore, it is argued in the literature that improvement of MSWM contributes to flood risk reduction. The review begins by tracing the typical cases from Asia and then from Africa. Overall, the review suggests that drainage blockage has remained a most challenging undertaking despite the milestones reported following the various initiatives that are being made to mitigate the problem.

In that regard, for example, a study has shown that in Mumbai, poor storm water drainage is a major contributory factor for the severity of regular monsoon flooding (Gupta, 2007 in Lamond et al., 2012). To overcome the problem, in a response to the 2005 flood, the state put in place a ban on the sale and use of plastic bags. However, this has not yet been effective due to lack of awareness and enforcement (UN-Habitat, 2010 as cited in Lamond et al., 2012). Similarly, in Jakarta, massive urbanization has led to reduction of storage areas for water throughout the city. In some responses to the recurrent flooding, local community based drain clearance, waste recycling and removal schemes were formed. As a result, the efforts have been successful in generating employment and raising the awareness on the importance of drainage, but the scale of the urban waste stream and the carriage of waste from upstream into the city means that the local efforts are not effective in reducing flood risk (Mercycorps, 2011, as cited in Lamond et al., 2012).

Additionally, In Managua, population growth has led to deficit in basic facilities and services and weak urban governance resulting in serious shortcomings in the refuse collection service (UN-Habitat, 2010 in Lamond et al., 2012). This has led to prevalence of flooding in the city.

In Africa, the most often cited flood was reported in Accra Ghana in 2007, and was linked especially to blocked drainage caused by poor waste management (Boadi \& Kuitunen, 2003). However, people in Accra are ignorant unaware of the drainage issues associated with flooding. To an extent they regard waste management as an issue that should be resolved exclusively by the government (Sam, 2009). Another flooding case has been reported in Maputo, where, during the 2000 flood, 70 percent of flood deaths were in urban areas near Maputo, mainly in the cities of Xai-Xai and Chokwe (UN-HABITAT, 2007). The governments liaised with the public through and endorsed public service contracts that institutionalized the primary collection as a free-of-charge public service for all residents (Kruks Wisner, 2006). However, despite this investment, flooding has remained a major problem. Moreover, a few months ago thousands of people in Maputo lost their lives, entire fishing communities were gone, tourist site flattened. This implies, a lot need to be done to lessen the impact of flooding.

Furthermore, a study done in Lagos city in Nigeria, revealed that in the informal settlements near the coast, flooding was one of the most serious problems they faced and poor waste management and clogged drains factored robustly in explaining the causes of the flooding (Lamond et al., 2012).

Furthermore, in 1999 in Bamako (the capital of Mali) flash flooding caused 
deaths and destruction. An analysis showed that poor waste disposal was a significant contributory factor (Setchell, 2008 as cited in Lamond et al., 2012). To overcome the problem, stakeholder participation, combined with a comprehensive planning framework, was used for the first time in the city. Ultimately, flood risk was reduced to some extent and Bamako has not experienced a similar flood disaster since 1999, mainly as a result of these initiatives (Setchell, 2008 as cited in Lamond et al., 2012).

\section{Conceptualizing Flood Risk Reduction}

The word risk has been defined as the combination of the probability of an event and its negative consequences (UNISDR, 2009). Therefore, in order to ensure that people live in an environment which is free from risks, there is a need to reduce them up to a minimal and acceptable level by investing in adaptation measures. This implies, in the absence of flood control measures community in flood prone settlements will be at great risk.

Keko Machungwa is a settlement that has been affected by flood risk as a result of combination of factors. First and foremost, the settlement is susceptible to a damaging effect of a hazard because of many aspects of vulnerability that exist. These include haphazard construction of building, poor solid waste management, absence of robust flood control structures, as well as the fact of being located in a hazard land (Sakijege et al., 2014). Moreover, like other flood prone settlements in Dar es Salaam, Keko Machungwa is part of the drowned valley (Temple, 1970). Second, being a part of Dar es Salaam, the settlement is also hit by heavy rainfall which causes hazard (i.e. flood). It is obvious that, when rainfall hit an area that is vulnerable (e.g. marked with absence of drainage system to drain storm water) the probability of being adversely affected becomes greater. For years, most of the settlements in the city of Dar es Salaam have been renowned as being in potential vulnerable situations (see for example Kebede \& Nicholls, 2012). Thus, when hit by any extreme events (e.g. rainfall) the settlements are easily adversely impacted as the case is in Keko Machungwa.

Even though the impacts of flooding cannot be prevented fully, their severity can be lessened using various strategies. One of the strategies is to improve solid waste management (UN-Habitat, 2010; Mercycorps, 2011; Kruks Wisner, 2006). Essentially, improvement of solid waste management means minimizing conditions of vulnerability that are present, which can help reducing susceptibility of the community to the damaging effects. In Tanzania, and the city of Dar es Salaam in particular, the extent to which flood risk is being reduced once solid waste management has been improved has not been extensively researched.

The extent to which flood risk had been reduced in Keko Machungwa was assessed using the following assessment criteria 1) amount of SW collected vs generated (UN-Habitat, 2010); 2) flood depths and number of buildings vulnerable to the impacts of flooding (Hall et al., 2003); 3) condition and capacity of flood control structures (Hall et al., 2005; Apel et al., 2004) and; 4) time that water stays in a settlement (Sakijege et al., 2012). 


\section{Methodology, Location and Population of the Study Area}

The study sampled an area called Keko Machungwa in Dar es Salaam. This is a settlement found in Miburani ward, which is within Temeke Municipality in Dar es Salaam, Tanzania. It is located $6^{\circ} 50^{\prime} 10^{\prime \prime}$ and $6^{\circ} 50^{\prime} 41^{\prime \prime}$ South and between longitude $39^{\circ} 16^{\prime} 35^{\prime \prime}$ and $36^{\circ} 17^{\prime} 1^{\prime \prime}$ East.

Keko Machungwa has a total of 4180 households, which is equivalent to 16,720 people given an average of 4 per household (URT, 2012). From 2012 (when the census was done) to 2019 (the time in which this research was carried out) the number of people is now considerably higher even if there was no in migration. Therefore, by using Geometric Method of population projection formula, the estimated population of Keko Machungwa as of 2019 is 24,485 people (equivalent to 6122 households). The geometric method of projection is given by: $P_{t}=P_{1}(1+r)^{n}$. whereas in this, case $P_{t}$ stands for Projected population, $\mathrm{P}_{1}$ stands for Population as per the recent census, $r$ stands for annual rate of the increase and $\mathrm{n}$ stands for number of years (see Table 1 ).

The reviewed literature focused on the concepts of MSWM improvement and flooding. On the other hand, the tools of data collections included physical observation, photographing, official interview and household interview were used to collect the primary information. In so far as the sapling techniques were concerned, purposive sampling was used to identify the households (70 households were interviewed) targeting the areas affected by floods so as to determine the extent to which flooding had been reduced after improvement of solid waste collection. Official interviews were held with Chairman of Jukwaa la Wanawake together with sub ward leader. Spatial information was collected using the GPS and spatial data were directly entered into GIS.

\section{Findings}

\subsection{Solid Waste Management Practices}

\subsubsection{Waste Generated in the Settlement}

Every person in Dar es Salaam produces a daily average of $0.9 \mathrm{~kg} /$ day per capita of household waste (NBS, 2017). Based on this analytical indicator, Keko Machungwa with a population of 24,485 produces an average of $22,036.5 \mathrm{~kg}$ daily (equivalent to 22.0365 tons). Furthermore, in a week, the settlement produces about $154,255.5 \mathrm{~kg}$ (equivalent to 154.255 tons). The produced wastes are in

Table 1. Items used for population projection.

\begin{tabular}{cl}
\hline Item & \multicolumn{1}{c}{ Details } \\
\hline $\mathbf{P}_{1}=\mathbf{P}_{2012}$ & $\begin{array}{l}\text { Population of Keko Machungwa in } 2012(16,720 \text { people }) \\
\mathbf{r}\end{array}$ \\
$\mathbf{n}$ & $\begin{array}{l}\text { Average growth rate for Dar es Salaam according to the census report of } \\
2012(\mathrm{r}=5.6)\end{array}$ \\
& Number of years between 2012 and $2019(\mathrm{n}=7$ years $)$ \\
\hline
\end{tabular}

Source: Data collected for the purposes of this study. 
many different forms and categorized in a variety of ways. The typologies of wastes produced comprise plastic materials (bottles, containers), metals (such as mosquito tins already used), glass materials (from utensils used at home), organic materials (e.g. from food). All these wastes must be disposed of correctly since they are hazardous and can harm people and the environment in general.

\subsubsection{Waste Collection and Transportation}

The study uncovered that waste collection and transportation at Keko Machungwa sub-ward is being done by an established women group called "Jukwaa la Wanawake", the term Jukwaa la Wanawake literally means "Women Participatory Group". This institution started operation in August, 2018. By the time this study was conducted, it had 8 members (all of them women). The main objective of forming this forum was to bring women together, with the underlined motive of resolving social problems, an instance of which being overcoming environmental pollution. The researcher was informed that the organization was already fully functioning and was being assisted by 40 women within the settlement. The responsibilities of the 40 women were three fold 1) to collect wastes collection fees; 2) encourage and insist people to collect their wastes in the waste collection points; 3) to clean wastes residual at the waste collection points after being transferred to the trucks. The 40 women work for about 10 days per month and they are paid Tshs. 30,000 (equivalent to $10.0 \mathrm{USD}^{3}$ ) per month.

\footnotetext{
"We are trying our level best to make our settlement clean, however, we need our government to support us"

"We as women, we face difficulties in convincing people to collect their wastes, they need to be educated about the importance of keeping our area clean"
}

Respondent 3 and 5

\subsubsection{Waste Collection Stations}

The study noted that the waste generators were the ones responsible for transferring their generated wastes to the collection points (see Plate 1), the collection points had been earmarked within few access roads (see Plate 1 and Map 1). The collection points are selected basing on the accessibility to the means of transport. Through observation, it was observed that larger part of Keko Machungwa subward (within the valley) is not planned, as such, it cannot easily be reached. This resulted to absence of waste collection points within the valley and all residents have to carry their solid waste to the collection points, this in turn simplifies waste collection.

All waste generators including households, food venders, guest houses, bars, pharmacies, shops, markets are responsible for transferring wastes from their

${ }^{3} 1$ USD is equivalent to $2315 \mathrm{Tshs}$

(source: https://www.xe.com/currencyconverter/convert/?Amount=1\&From=USD\&To=TZS viewed 24 August, 2019). 

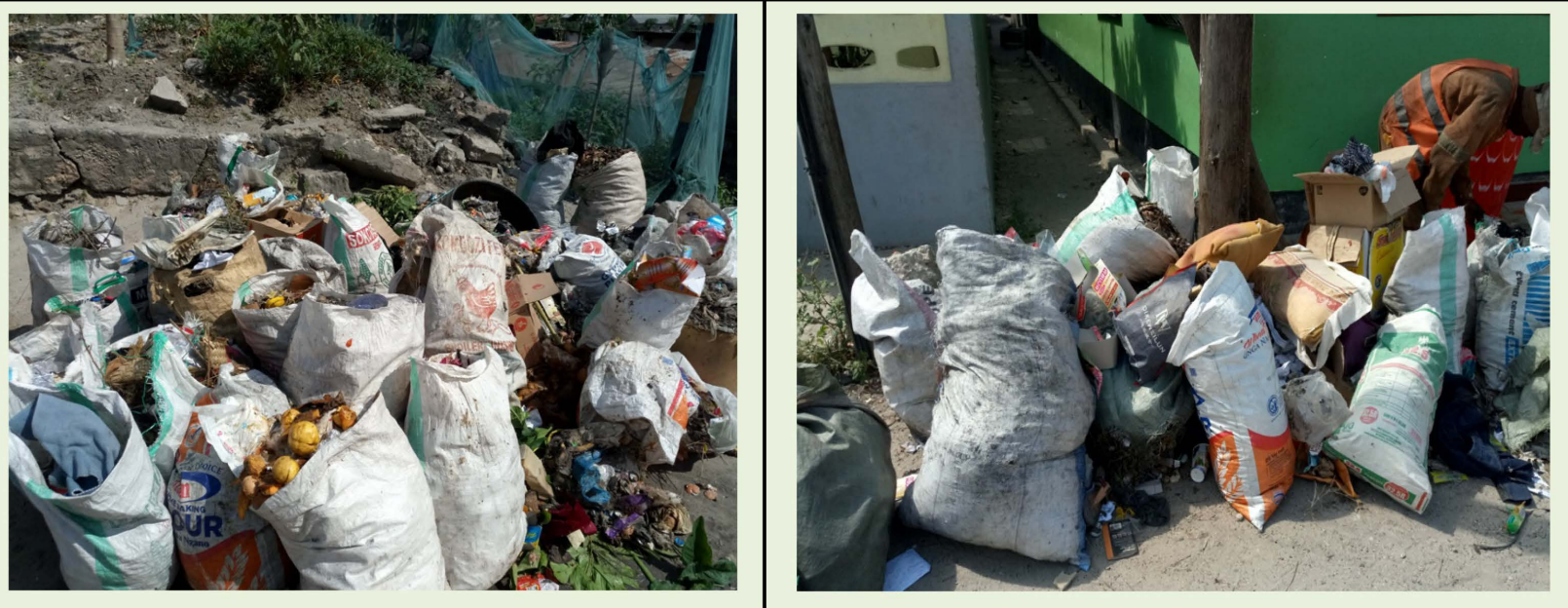

Plate 1. SW in some waste collection points. Source: Photographed by Tumpale Sakijege, 14 July 2019.

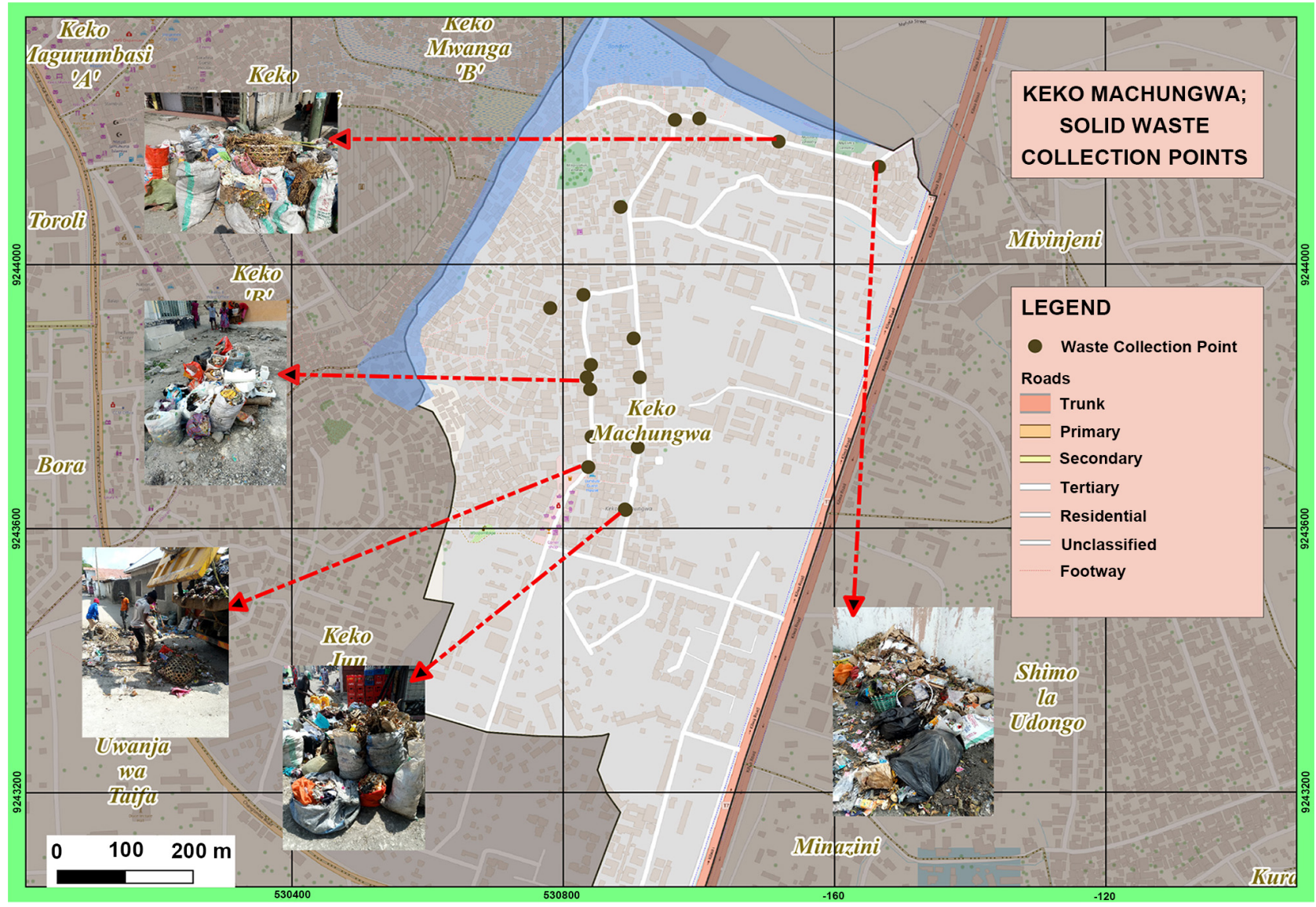

Map 1. Solid waste collection points in different parts of the settlement. Source: Map created by the author for the purposes of this study.

houses to the collection centers. These centers are the areas that are easily accessible by trucks. The notable positive point in the settlement was that those who accept to pay for the SW collection fee had no obligations of carrying their waste to the collection points. 


\subsubsection{Waste Transportation}

The researcher observed that Jukwaa la Wanawake use Municipal truck to transport collected solid waste to disposal sites (Plate 2). In addition truck operators were the ones responsible for delivering wastes to the truck ready for transportation to designated disposal sites from wastes collection stations. Saturday is the only day in a week that has been selected for collection and transportation of wastes. Truck operators are required to pick wastes that are either in a dustbin or separate sulphate and pour them into the trucks. However, it was reported that at times they face difficulties especially when people decide to pour wastes in the collection points. On top of that, in some of the days (especially end of the month) due to size of the car and volume of the solid wastes generated, they fail to transport wastes in a single trip, which adds unnecessary costs. At times, they are forced to do transportation activities in Sundays, the situation which brings a lot of complaints among the residents who live closer to the SW collection stations.

"There are times we face a challenge of smell of bad odors from the wastes remain around for a day or more. Quite often, the exercises are extended to Sunday due to technical problems of the trucks. When trucks come late in the evening hence forced to overstay to the following day (Sunday), we are exposed to intolerable filth causing bad odor. The trash produces an acrid and offensive smell which is so dangerous particularly to our children".

Respondent 7

The foregoing account implies that delays in transporting wastes to the landfill potentially leads to environmental hazards in the surrounding environment.

\subsubsection{Waste Collection Fee}

Solid wastes collection fee differs depending on the source of generation. As demonstrated by Table 2, the monthly fee for each household is Tshs 3000/=. Keko Machungwa had 4180 households, which indicates that if every household had to pay SW fee, about 12,540,000 would be collected per month. However, it seemed it was evidently a challenge to get this amount due to the fact that some household were not willing to pay for the services. Other waste generation sources were reported to be paying SW monthly fee of between 4000 (e.g. shops) and 6000 (e.g. butchery).

\subsection{Challenges Faced by Jukwaa la Wanawake in Solid Waste Management}

\subsubsection{Waste Management and Transportation Costs}

Jukwaa la Wanawake at Keko Machungwa had 1 year since its establishments. Given the relatively short span of time it had been operating, it was therefore 


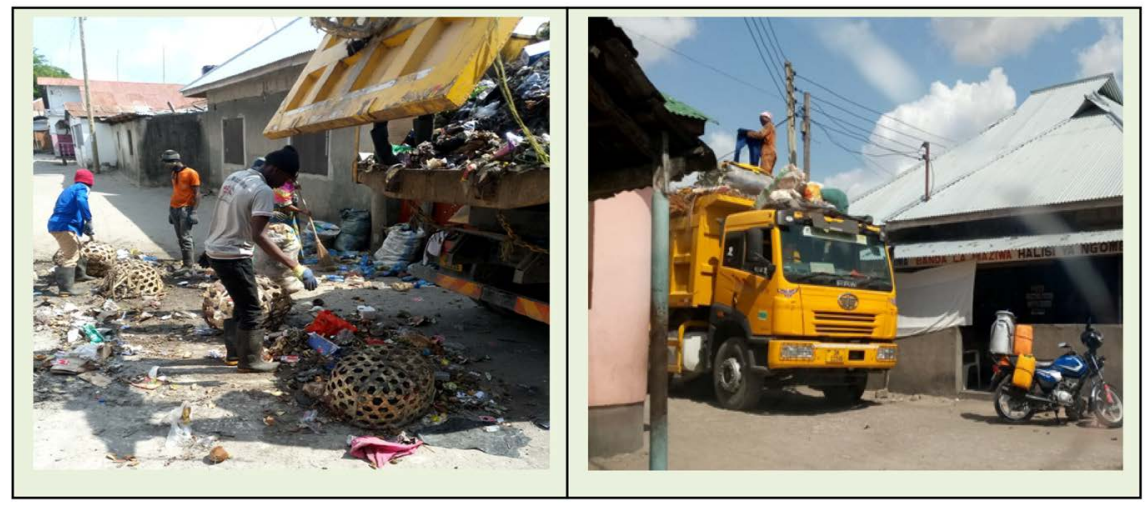

Plate 2. Municipal truck in operation at Keko Machungwa. Source: Photographed by Tumpale Sakijege, 14 July 2019.

Table 2. SW fee per month.

\begin{tabular}{cc}
\hline Waste generation source & Fee charged per month \\
\hline Shops & 4000 \\
Food venders & $2000-4000$ \\
Households & 3000 \\
Tailors & 4000 \\
Market & $4000-6000$ \\
Guest houses & 6000 \\
Charcoal sellers & 4000 \\
Butchery & 6000 \\
\hline
\end{tabular}

Source: Data collected for the purposes of this study.

facing a number of challenges. One of the biggest challenges was the capital required to buy equipment like broom, wheel barrows and megaphones, among others. They also needed to have their own office and own truck so as to minimize transportation cost. By the time the study was conducted, the moment they were found using Sub-ward office which had limited space and was very busy. The lack of enough capital to pay for more trip especially at the end of the month when ton of wastes generated increases also imposed a significant constraint.

About 40 tons of wastes were reported to be collected every Saturday. The wastes were being transported to a waste disposal site. In order to transport the 40 tons generated, truck from the municipal was being hired at the price of TZs $200,000 /=$ per trip. The trucks that were normally being hired had the capacity to carry 12 tons. This means that the trucks had go and return 3 times to finish the collected heap of wastes. For a month with 4 and 5 weeks, the organization was obliged to pay Tshs 2,400,000 $(200,0003 \times 4)$ and Tshs 3,000,000 (200,000 3 $\times 5)$ respectively. Furthermore, when the Municipal truck had any technical problem and the maintenance was delayed, the organization was forced to hire private truck at the cost of Tshs 500,000 per trip, which was very expensive. 


\subsubsection{Schedule of the Truck}

The truck had been planned to service Keko Machungwa on Saturday, however, due to the fact that Jukwaa la Wanawake had no control of the truck the specific time is not known and thus forced to follow undefined operation schedules of truck. At times they get service on either Saturday morning, afternoon or evening. Although it was clearly known that every Saturday the truck collects SW, the specific time was highly unpredictable. In view of the Chairman who was interviewed and also about $67 \%$ of the interviewed residents, there was a general consensus that usually the truck provided service in the settlement on Saturday but at a defined specific time so that the community had to bring wastes early before the truck arrives. Additionally, owing to the fact that they depended almost entirely on the Municipal truck, when there was any default that implied the SW would remain uncollected until the truck default was fixed. This was very risk given the fact that there were children who usually play in the same streets. The wastes contain hazardous materials (e.g. expired medicines, broken bottles) which are dangerous to kids.

\subsubsection{Hardship in Collecting Fee}

Approximately 40 women who were responsible for collecting solid wastes had organized themselves into sub groups in-order to enhance simplicity of waste collection in 25 fifty cells. To identify the household in each of the fifty cells, they were being helped by the cell leaders. Furthermore, the SW fee collection was a challenge given the fact that there was little community awareness. The women entitled to collect SW fee were being compelled to walk from one house to another in order that they could reach every household. Meanwhile, in some other households, they had to go several times per month. A number of reasons accounted for this scenario, as follows 1) some were leaving very early in the morning and return late in the evening, 2) others were failing to pay on time for the reason of life hardships, 3) a few others refuse to pay for the reason that they were not generating wastes, 4) others hide themselves when they sense that someone would be coming to collect the fee. Moreover, the Chairman of the Jukwaa la Wanawake also participate in collecting SW fee especially to many who usually refuse to pay. The Chairman also participates in making some good arrangements with those who produce wastes other than the households (for example guest houses, shops and market, among others). She also collaborates with the Ward police to conduct surprise visits to those houses whose owners hardly contribute to the SW collection fee, as expounded that:

We are forced to work at night in order to collect fee for those who usually come late and leave early in the morning. We are also assisted by the Ward police to collect fee from those who usually refuse to pay. Working at night has been a challenge because we sometimes encounter robbers.

Chairman 


\subsubsection{Little Awareness among the Residents}

There is little awareness among the residents, whereby, majority (73.5\% of the interviewees) considered waste collection as a useless exercise, which implied they were not supposed to pay for. Most of these were those who live in the river valley of Keko Machungwa and take advantage of the river to throw their wastes in it. However, Jukwaa la Wanawake in collaboration with sub-ward office set up some rules, whereby, whether one produced wastes or not so long as he/she was residing in the settlement, it was mandatory to pay TZs 3000/=. If caught throwing waste into the river, one would be liable for a fine of Tshs 50,000/=. These communities driven by laws to a larger extent had helped Jukwaa la Wanawake to collect substantial amount of money as basket fund allowing them to manage waste collection and transportation. The researcher observed that the situation which was witnessed by Kasala (2014) who found settlement pathetic with filth had changed to the good, for at least there was less accumulation of solid waste in the river (see Plate 3).

\subsubsection{Failure of Members to Pay Fee on Time}

Due to life hardships, the households sampled and studied had been delaying in paying waste collection fee on time, a tendency that disrupted the smooth operation of waste transportation due to the fact that the Jukwaa la wanawake collect less tons than expected. In turn, it leads to failure to pay consultation fees on time. Furthermore, the 40 women had other economic activities; therefore, they waste a lot of time following community members who keep on postponing the payments and at times the TZs contribution fees amounting to 3000 was being paid in installments.

\subsubsection{Absence of Wastes Containment Facilities}

The study revealed that waste collection stations were not served with waste containment facilities; therefore the waste generators were carrying wastes in plastic bags and few in dustbins and transfer them to the collection points (see Plate 1).

\subsection{Extent of Flood Risk Reduction}

\subsubsection{Solid Waste Collected}

One of the objectives of improving Solid Waste collection is to minimize the haphazard associated with dumping of solid waste that has been blocking drainage channels, consequently leading to flooding. When comparing the amount of solid waste generated and collected, the study revealed that 154.2 tons of wastes were being generated every week, while 40 tons are collected and transported to disposal sites. This shows that only $25.9 \%$ of the generated wastes are being collected despite the initiatives made while $74.1 \%$ remained uncollected. The finding resonate those by Memon (2010) and Kaza et al. (2018) who established that the amount of waste collected by most developing countries does not reach $50 \%$ despite the effort invested. However, reflecting on a study done by Kasala (2014), about 31 tons of wastes were being collected per week in 2014, which implies that between 2014 and 2019, there has been an increase of 9 tons 


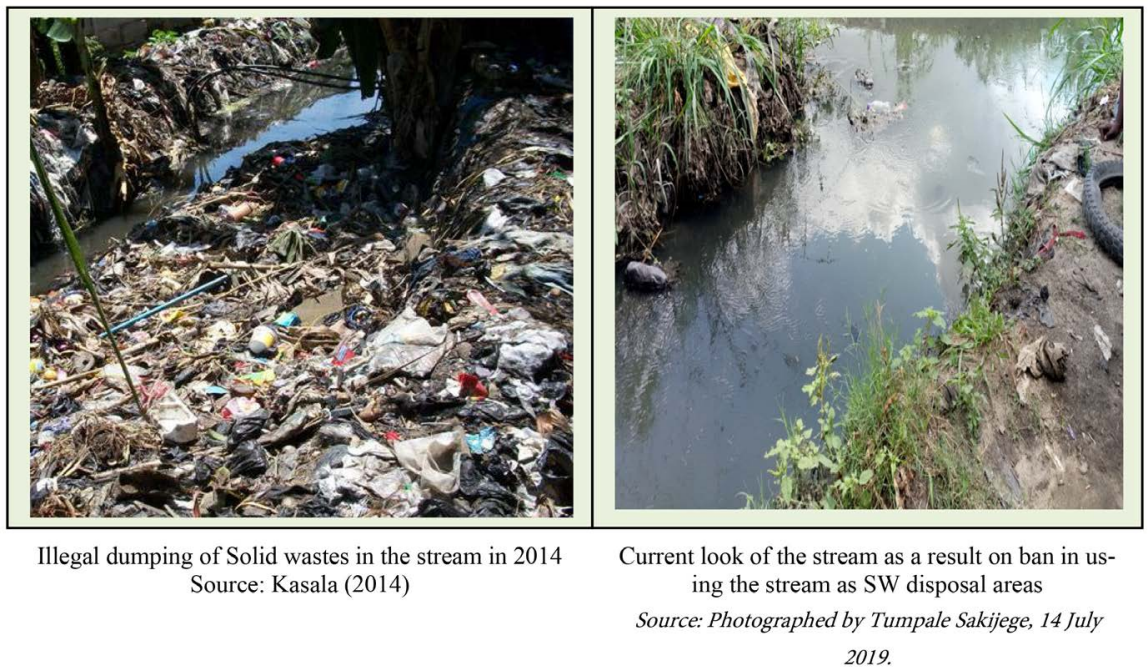

Plate 3. Situation of solid waste in Keko Machungwa stream before and after improvement of SWM.

of collected waste per week. This increase might have resulted from the current initiatives. However, as the tons of the collected waste are only $25.9 \%$, it means the remaining $74.1 \%$ are being disposed through other unwanted means (e.g. throwing on the streams). This was an indication that the flood risk would hardly be reduced given the less tons of SW collected.

Through observation in different parts of the settlement (including along the stream) the study confirmed that pollution from open dumping had been reduced to a largest extent. The streams seemed to be free from wastes (Plate 3). However, in the nearby settlements (downstream), there were heaps of collected waste (see Plate 4). It was difficult to conclude whether the wastes were from within Keko Machungwa or they had been transported from other settlements in which the river traversed. The fact that not all generated wastes were been collected as elaborated in the foregoing paragraph, was a clear indication that the community within the settlements (especially those close to the stream) were disposing wastes in the vicinity of the stream. The accumulated wastes downstream could block the water flow, leading to flooding in Keko Machungwa.

When asked what improvements need to be made in regard to the prevailing practice of solid waste management in Keko Machungwa, the response across the majority of the households (68\%) who live within the valley pointed out the walking distance to waste transfer stations. The highest travel figure reported was $0.6 \mathrm{~km}$, they therefore required to have people who could walk from house to house in order to assist in carrying wastes to the collection/transfer stations. Inaccessibility is attributed to the haphazard housing construction thereby making trucks unable to reach the waste generation spot.

\subsubsection{Flood Depth and Affected Buildings}

Keko Machungwa is amongst the settlements in Dar es Salaam that are mostly affected by floods every rainy season partly also because of the fact that part of 


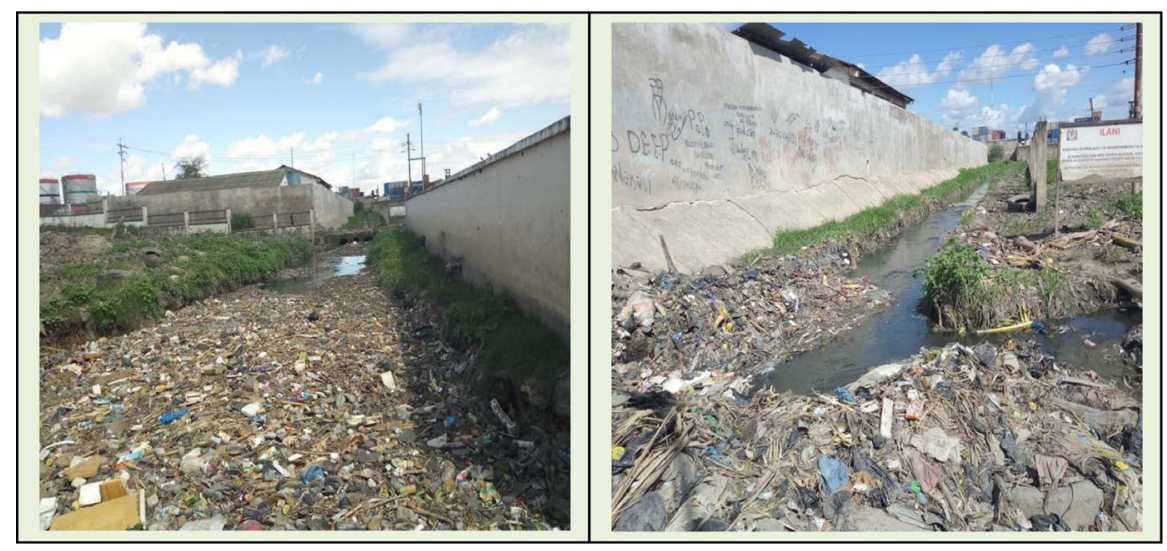

Plate 4. Heap of uncollected waste in Matangini Street. Source: Photographed by Tumpale Sakijege, 14 July 2019.

the settlement is in deep valley and the walls of the constructed buildings have distorted the drainage. Hence, the landscape of the valley contributes to surface runoff from the surrounding elevated areas. Sakijege et al. (2014) reported that during severe events (excess rainfall) the water depth in the settlement reaches $1.5 \mathrm{~m}$ and 150 houses are inundated by flooding. The findings of this study revealed that about 150 houses in the settlement were frequently affected by flooding and the flood depth reached about 1.49 meters. This means that there was no significant reduction in the flood depth despite the improvements made in the solid waste collection. Thus, more efforts are needed.

\subsubsection{Time that Water Stay in the Settlement}

The household interview revealed that $31.6 \%$ of the respondents reported duration of the problem of flooding of 5 months, $23.1 \%$ (reported three days), $12.4 \%$ (7 days), 10.9\% (a year) and the remaining (22) were affected by floods for some hours (their houses flooded when raining and the flood tend to stop few hours after rains stopped). About $10.9 \%$ of those affected throughout the year faced the problem of water originating from the ground, technically, this problem is referred to as groundwater flooding and mostly affects low lying areas (Foster et al., 2002). It should be pointed out that; water table in the settlement (the area within the valley) is high; therefore, the soil is saturated such that it cannot easily allow smooth infiltration.

People who reported to be affected by floods throughout the year had abandoned their houses and relocated to other settlements, the main reason being the groundwater flooding throughout the year. They tried to rent the houses, but due to the mentioned problem they were not getting customers (see Plate 5 and Map 2 for the plates and map that show location of some abandoned houses).

\subsubsection{Condition and Capacity of Flood Control Structures}

It was important to investigate the condition and availability of flood control structures because solid waste management as among the initiatives to minimize blockage of drains and hence reduce flooding need to be integrated with other 

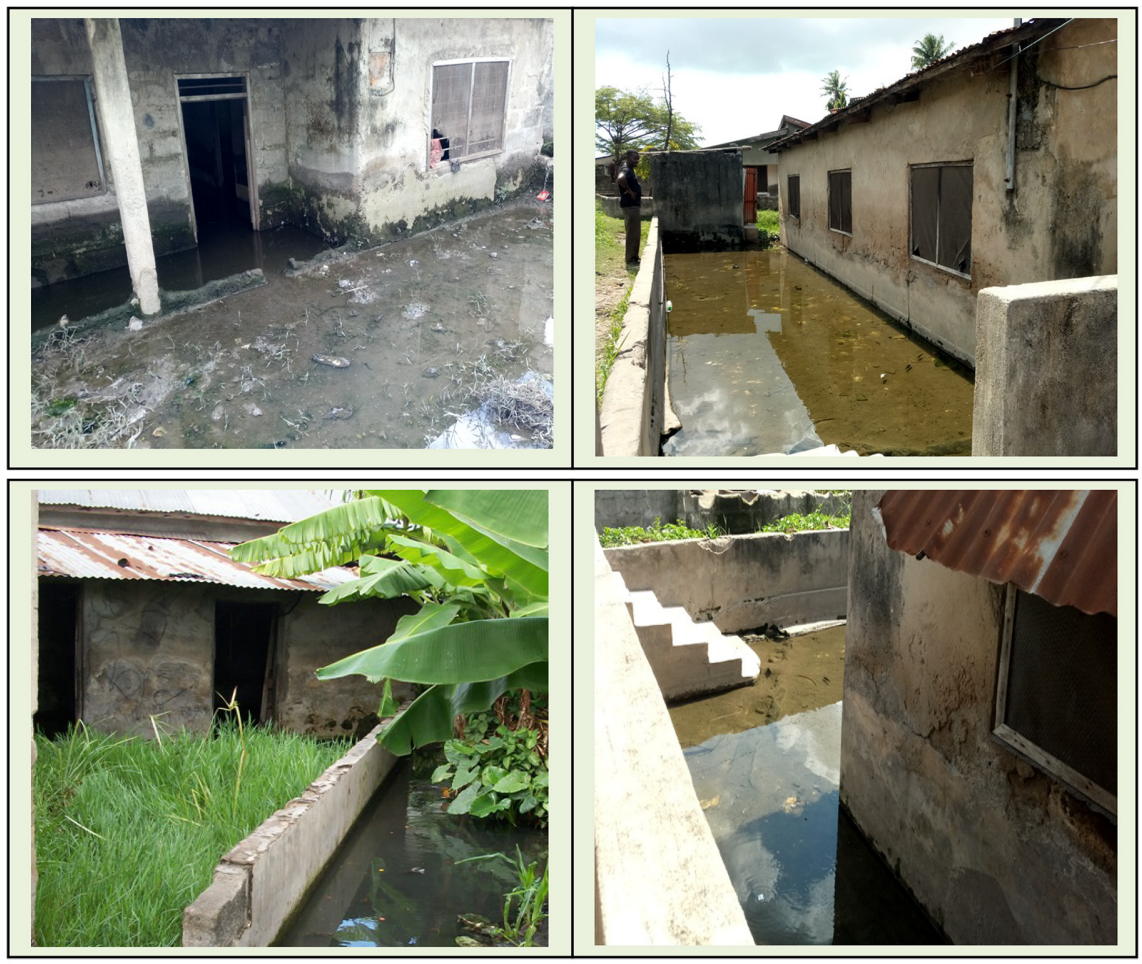

Plate 5. Some of the abandoned houses in the settlement. Source: Photographed by Tumpale Sakijege, 14 July 2019.

means. In the past years, Keko Machungwa lacked robust flood control structure at community level; hence the ongoing initiatives were being done individually and were fragmented, hence were not that effective in minimizing flood risks. The stream that traverses the settlement is the one used to drain water outside the settlement towards the Indian Ocean. This stream apart from lacking embankment on its side, it was narrowing due to absence of guidance in the construction of houses done by the community. The community had built houses up to the edge of the river. It was therefore difficult to judge the flood risk reduction basing on one cause (i.e. solid waste) while other vulnerability situation were still present, hence reducing susceptibility of the community.

\section{Discussion}

The SWM in Keko Machungwa by Jukwaa la Wanawake was initiated in 2018. The evidence from the conducted household interview has shown that Jukwaa la Wanawake had managed to convince residents to participate in making their settlement clean by engaging themselves in proper ways of solid waste disposal. They were able to convince majority of solid waste generators to carry their wastes to transfer stations. Furthermore, the observation confirmed that different parts of the stream had no wastes as it was previously in the past seven years, which indicated a significant improvement (UNEP, 2010). However, accumulation of waste somewhere beyond the settlement was an indication that some 


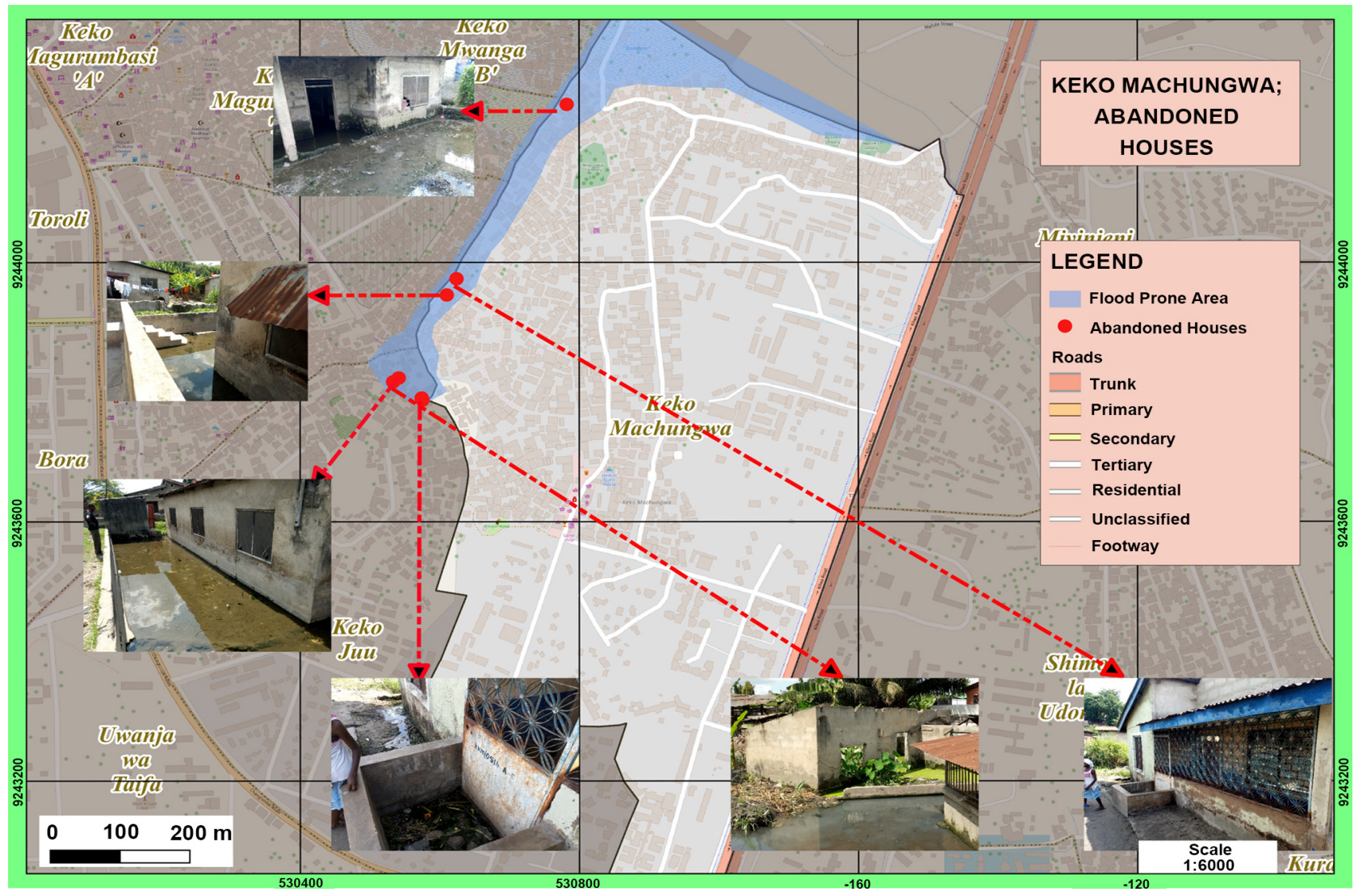

Map 2. Some of abandoned houses in Keko Machungwa. Source: Map created by the author for the purposes of this study.

members still practice poor solid waste disposal secretly (possibly at night). Moreover, the collected waste (40 tons per week) out of 154.255 generated indicates that, most likely, the remaining uncollected waste (114.2 tons) is slowly disposed of through the stream that traverses the settlement. This might accentuate environmental and public health risks if efforts are not being made to increase the capacity of solid waste collection from merely 40 tons.

Given the current positive response from the community, if organized properly, Jukwaa la Wanawake had the capacity to ensure that at least $90 \%$ large part of the generated wastes are transferred to the collection points. This argument is raised based on the following reasons 1) there existed mechanisms of insisting people to pay for the waste collection fee even if in circumstances in which one claimed not to produce waste. This had an indirect implication in making people feel uncomfortable to throw waste in streams. The forum should use this opportunity to increase efforts to convince the community on the importance of keeping their environment clean. 2) The truck that is used to transfer waste to waste disposal site is available at a reasonable price (i.e. 200,000 per trip), unlike private trucks (which were charging 500,000 per trip). This means they had reliable cost effective means of transport. 3) There were plans to solicit funds from other sources (borrowing from banks) and also through collaborating with other partners (sub-wards within Miburani ward) who could assist to buy their own truck. 
By the time the study was carried out, the SWM system in Keko Machungwa was being done almost exclusively through collecting and transporting SW to the disposal sites. The issues pertaining to recycling had not been initiated. As aptly remarked, recycling provides significant economic benefits and presents opportunities to societies (Wilson et al., 2006).

The study revealed that improved solid waste management does not contribute to flood risk reduction (see Section 5.3). As the study has demonstrated, in Keko Machungwa, a number of households are still affected by flooding despite the improvements made in solid waste management. The finding that improved solid waste management hardly contribute to flood risk reduction is also confirmed by other studies from other cities of the world (UN-Habitat, 2010; Mercycorps, 2011; Kruks Wisner, 2006). In fact, flooding is a common phenomenon in most of the informal settlements in the city of Dar es Salaam. Apart from complaints that solid waste usually block drainage channel and thus reduce the capacity of the same to allow easily flow of storm water and consequently lead to flooding, this study proved otherwise. In fact, solid waste is not the main factor that contributes to flooding.

Observation and photographing was done frequently between May-July so as to substantiate the claim that some houses are inaccessible throughout the year. In Tanzania and Dar es Salaam in particular May-July are considered to be dry months. Thus, it was expected to find no houses surrounded by water. Strangely, the study found that there were a number of abandoned houses which had been surrounded by water. The colour of water had changed to green, indicating that water had been stagnant for a very long period. These houses were those that had been constructed up to the edge of the stream that traverse the settlement. The houses that are surrounded by water are no longer in use, owners decided to relocate to other areas. The abandoned houses make the settlement look bad, moreover there are overgrown grasses and pest. The abandoned houses are hazardous in the sense that they can be hot beds for criminal activity and the pest can spill over to other houses.

The concept of managing flood risk is receiving increased attention by many experts in the developing countries and throughout the world. This is because floods have affected more people than any other type of natural hazard in the 21st century (UNISDR, 2019). In Tanzania, the nature of risks and the impacts caused by floods to the community and economy is clearly understood (Augustijn-Beckers et al., 2011; Sakijege et al., 2012; Sugar et al., 2013). Despite this awareness and possibly due to financial constraints, the governments do not seem to engage in helping the community to minimize flood impact. A good example is the situation that the study revealed in Keko Machungwa settlement. Apart from solid waste, the settlement needs assistance in controlling flooding by investing in disaster risk reduction measures (e.g. construction of drainage channel) which can directly contribute to better adaptation of the settlement.

The study has established a notable number of houses that had been abandoned for the reason of inaccessibility due to ground water flooding. Formerly, 
part of the valley was earmarked as hazard land and not suitable for development (URT, 1968). Presence of houses in a hazard land and up to the edge of the stream indicates laxity in implementing our own laws. In other words, if the hazard area within Keko Machungwa was not occupied possibly flood risk would have been minimal.

\section{Conclusion}

The main finding is that although improved MSW collection is so important, it is not the only driving force behind flood risk reduction. However, improvement of SWM in the settlement like Keko Machungwa has the prospective of reducing flood risks if integrated with other flood risk reduction initiatives. Different factors that influence flood risk in Keko Machungwa should therefore be taken into consideration when planning the measures for flood risk reduction.

Engagement of Jukwaa la Wanawake in SW collection is helpful in increasing awareness within the settlement and in motivating community members to practice proper solid waste disposal. The same technique can be used in flood management, Jukwaa la Wanawake can use this opportunity to educate the community on flooding issues. They could discuss and agree on how everyone should participate in minimizing flood risk.

Moreover there is a need for flood risk reduction initiatives to be done in a large scale. The current initiatives in which each settlement devises its own means have proven to be ineffective. Instead of continuing with the current arrangement in which each sub-ward or ward formulate their own ways of minimizing flood risks (e.g. through collecting solid wastes), the government through the responsible ministry should establish a system to be followed by all flooded settlements so as to avoid the transfer of floods to the nearby settlements. For example, if we aim to minimize flood risk by improving solid waste management, then each settlement (upstream and downstream) should focus on that so as to minimize the accumulation of wastes downstream, which could contribute significantly towards reducing blockage.

It is also worth emphasizing that urban planning and disaster management policies should focus on monitoring developments in hazardous areas. The main message from the study is that community in Keko Machungwa is still affected by flooding even after improvement in solid waste collection. This is because other vulnerable conditions in the settlement still exist. A good example is the presence of houses in hazard area (up to the edge of the stream and most of them are the ones affected by flooding) while laws which prohibit development in such areas exist. It is inevitable that the existing building structures located in the water way in Keko Machungwa should be demolished.

\section{Acknowledgements}

The support of Amedeus Kimaro with spatial data collection in Keko Machungwa is gratefully acknowledged. 


\section{Funding}

This research received no external funding.

\section{Conflicts of Interest}

The author declares no conflicts of interest regarding the publication of this paper.

\section{References}

Abdrabo, M. A. (2008). Assessment of Economic Viability of Solid Waste Service Provision in Small Settlements in Developing Countries: Case Study Rosetta, Egypt. Waste Management, 28, 2503-2511. https://doi.org/10.1016/j.wasman.2007.10.017

Agbola, B. S., Ajayi, O., Taiwo, O. J., \& Wahab, B. W. (2012). The August 2011 Flood in Ibadan, Nigeria: Anthropogenic Causes and Consequences. International Journal of Disaster Risk Science, 3, 207-217. https://doi.org/10.1007/s13753-012-0021-3 https://link.springer.com/article/10.1007/s13753-012-0021-3

Andrianisa, H. A., Brou, Y. O. et al. (2016). Role and Importance of Informal Collectors in the Municipal Waste Pre-Collection System in Abidjan, Côte d'Ivoire. Habitat International, 53, 265-273. https://doi.org/10.1016/j.habitatint.2015.11.036

Apel, H., Thieken, A. H., Merz, B., \& Blöschl, G. (2004). Flood Risk Assessment and Associated Uncertainty. Natural Hazards and Earth System Science, 4, 295-308. https://doi.org/10.5194/nhess-4-295-2004 https://hal.archives-ouvertes.fr/hal-00299118/document

Augustijn-Beckers, E. W., Flacke, J., \& Retsios, B. (2011). Simulating Informal Settlement Growth in Dar es Salaam, Tanzania: An Agent-Based Housing Model. Computers, Environment and Urban Systems, 35, 93-103. https://doi.org/10.1016/j.compenvurbsys.2011.01.001

Babalola, A., Ishaku, H. T., Busu, I., \& Majid, M. R. (2010). The Practice and Challenges of Solid Waste Management in Damaturu, Yobe State, Nigeria. Journal of Environmental Protection, 1, 384. https://doi.org/10.4236/jep.2010.14044

Boadi, K. O., \& Kuitunen, M. (2003). Municipal Solid Waste Management in the Accra Metropolitan Area, Ghana. Environmentalist, 23, 211-218. https://doi.org/10.1023/B:ENVR.0000017283.09117.20 https://link.springer.com/article/10.1023/B:ENVR.0000017283.09117.20

Bubegwa, S. (2012). An Overview of Solid Waste Management in the City of Dar es Salaam. In The Coast East Africa Solid Waste Management and Gas to Energy Best Practices Workshop. https://www.globalmethane.org/documents/events_land_120910_12.pdf

Foster, S., Hirata, R., Gomes, D., D’Elia, M., \& Paris, M. (2002). Groundwater Quality Protection: A Guide for Water Service Companies, Municipal Authorities and Environment Agencies. Washington DC: The World Bank. https://doi.org/10.1596/0-8213-4951-1

Hall, J. W., Dawson, R. J., Sayers, P. B., Rosu, C., Chatterton, J. B., \& Deakin, R. (2003). A Methodology for National-Scale Flood Risk Assessment. Proceedings of the Institution of Civil Engineers-Water Maritime and Engineering, 156, 235-248. https://doi.org/10.1680/wame.2003.156.3.235 https://www.researchgate.net/profile/Richard_Dawson/publication/245412992_A_methodolog yfor_national-scale_flood_risk_assessment/links/02e7e538eede736a88000000/A-methodologyf 
ornational-scale-flood-risk-assessment.pdf

Hall, J. W., Sayers, P. B., \& Dawson, R. J. (2005). National-Scale Assessment of Current and Future Flood Risk in England and Wales. Natural Hazards, 36, 147-164. https://doi.org/10.1007/s11069-004-4546-7

Kasala, S. E. (2014). Critical Analysis of the Challenges of Solid Waste Management Initiatives in Keko Machungwa Informal Settlement, Dar es Salaam. Journal of Environmental Protection, 5, 1064. https://doi.org/10.4236/jep.2014.512105

Kassim, S. M., \& Ali, M. (2006). Solid Waste Collection by the Private Sector: Households' Perspective-Findings from a Study in Dar es Salaam City, Tanzania. Habitat International, 30, 769-780. https://doi.org/10.1016/j.habitatint.2005.09.003

Kaza, S., Yao, L., Bhada-Tata, P., \& Van Woerden, F. (2018). What a Waste 2.0: A Global Snapshot of Solid Waste Management to 2050. Urban Development Series. Washington DC: World Bank. https://doi.org/10.1596/978-1-4648-1329-0

Kebede, A. S., \& Nicholls, R. J. (2012). Exposure and Vulnerability to Climate Extremes: Population and Asset Exposure to Coastal Flooding in Dar es Salaam, Tanzania. Regional Environmental Change, 12, 81-94. https://doi.org/10.1007/s10113-011-0239-4

Kouloughli, S., \& Kanfoud, S. (2017). Municipal Solid Waste Management in Constantine, Algeria. Journal of Geoscience and Environment Protection, 5, 85-93. https://doi.org/10.4236/gep.2017.51006

Kruks Wisner, G. (2006). After the Flood: Crisis, Voice and Innovation in Maputo's Solid Waste Management Sector. Doctoral Dissertation, Cambridge, MA: Massachusetts Institute of Technology. https://dspace.mit.edu/handle/1721.1/37672

Lamond, J., Bhattacharya, N., \& Bloch, R. (2012). The Role of Solid Waste Management as a Response to Urban Flood Risk in Developing Countries, a Case Study Analysis. WIT Transactions on Ecology and the Environment, 159, 193-204. https://doi.org/10.2495/FRIAR120161

Lohri, C. R., Camenzind, E. J., \& Zurbrügg, C. (2014). Financial Sustainability in Municipal Solid Waste Management-Costs and Revenues in Bahir Dar, Ethiopia. Waste Management, 34, 542-552. https://doi.org/10.1016/j.wasman.2013.10.014

Mbuligwe, S. E., Kassenga, G. R., Kaseva, M. E., \& Chaggu, E. J. (2002). Potential and Constraints of Composting Domestic Solid Waste in Developing Countries: Findings from a Pilot Study in Dar es Salaam, Tanzania. Resources, Conservation and Recycling, 36, 45-59. https://doi.org/10.1016/S0921-3449(02)00009-5

Memon, M. A. (2010). Integrated Solid Waste Management Based on the 3R Approach. Journal of Material Cycles and Waste Management, 12, 30-40. https://doi.org/10.1007/s10163-009-0274-0

Mercycorps (2011). Community Based Flood Risk Management Initiatives. In Learning from Flood Risk Reduction Projects in Jakarta Presentation in the Consultation Workshop Preparation of a Global Handbook for Urban Flood Risk Management, Jakarta, 25-26 May 2011.

Nagabooshnam, J. K. (2011). Solid Waste Generation and Composition in Gaborone, Botswana, Potential for Resource Recovery. Linköping: Linköping University.

National Bureau of Statistics (NBS) Tanzania (2017). National Environment Statistics Report (NESR, 2017)_Tanzania Mainland. Dar es Salaam.

https://unstats.un.org/unsd/environment/Compendia/United\%20Republic\%20of\%20T anzania,\%20National\%20Environment\%20Statistics\%20Report,\%202017.pdf

Okot-Okumu, J. (2012). Solid Waste Management in African Cities-East Africa. In L. Fernando, \& M. Rebellon (Eds.), Waste Management-An Integrated Vision (pp. 
3-20). London: IntechOpen. https://doi.org/10.5772/50241

Rasmussen, M. I. (2013). The Power of Informal Settlements. The Case of Dar es Salaam, Tanzania. Planum-The Journal of Urbanism, 1, 26. http://www.hdm.lth.se/fileadmin/hdm/Education/Research/12_CTBT2012_by_Planum _no_26-2013_Rasmussen_Section_1-1_5_.pdf

Sakijege, T., Lupala, J., \& Sheuya, S. (2012). Flooding, Flood Risks and Coping Strategies in Urban Informal Residential Areas: The Case of Keko Machungwa, Dar es Salaam, Tanzania. Jàmbá: Journal of Disaster Risk Studies, 4, a46. https://doi.org/10.4102/jamba.v4i1.46

Sakijege, T., Sartohadi, J., Marfai, M. A., Kassenga, G., \& Kasala, S. (2014). Government and Community Involvement in Environmental Protection and Flood Risk Management: Lessons from Keko Machungwa, Dar es Salaam, Tanzania. Journal of Environmental Protection, 5, 760. https://doi.org/10.4236/jep.2014.59078

Salami, R. O., Von Meding, J. K., \& Giggins, H. (2017). Urban Settlements' Vulnerability to Flood Risks in African Cities: A Conceptual Framework. Jàmbá: Journal of Disaster Risk Studies, 9, a370. https://doi.org/10.4102/jamba.v9i1.370

Sam, P. A. (2009). Are the Municipal Solid Waste Management Practices Causing Flooding during the Rainy Season in Accra. Ghana: Ghana Resource Centre.

Sugar, L., Kennedy, C., \& Hoornweg, D. (2013). Synergies between Climate Change Adaptation and Mitigation in Development: Case Studies of Amman, Jakarta, and Dar es Salaam. International Journal of Climate Change Strategies and Management, 5, 95-111. https://doi.org/10.1108/17568691311299381

Temple, P. H. (1970). Aspects of the Geomorphology of the Dar es Salaam Area. Tanzania Notes and Records, 71, 21-54.

UN International Strategy for Disaster Reduction (UNISDR) (2009). Terminology on Disaster Risk Reduction. Geneva: UNISDR. https://www.unisdr.org/we/inform/publications/7817

UNEP (2010). Solid Waste Characterization and Quantification of Bahir Dar City for the Development of an ISWM Plan. Forum for Environment, June 2010.

UN-HABITAT (2007). Bamako-Using Partnerships to Support Environmental Management.

Un-Habitat (2010). Solid Waste Management in the World's Cities. London: Routledge. https://doi.org/10.4324/9781849774871

United Nations UN Department of Economic and Social Affairs, Population Division (2018). The World's Cities in 2018-Data Booklet (ST/ESA/SER.A/417).

https://www.un.org/en/events/citiesday/assets/pdf/the_worlds_cities_in_2018_data_bo oklet.pdf

United Republic of Tanzania (URT) (1968). The National Capital Master Plan, Dar es Salaam, Technical Supplement No. 4: City Form and Environment. Toronto: Project Planning Associates Limited.

United Republic of Tanzania (URT) (2012). Census Report, Government Printers, Dar es Salaa.

Wilson, D. C., Velis, C., \& Cheeseman, C. (2006). Role of Informal Sector Recycling in Waste Management in Developing Countries. Habitat International, 30, 797-808. https://doi.org/10.1016/j.habitatint.2005.09.005

Yukalang, N., Clarke, B., \& Ross, K. (2018). Solid Waste Management Solutions for a Rapidly Urbanizing Area in Thailand: Recommendations Based on Stakeholder Input. International Journal of Environmental Research and Public Health, 15, 1302. 
https://doi.org/10.3390/ijerph15071302

Zhu, D., Asnani, P. U., Zurbrügg, C., Anapolsky, S., \& Mani, S. (2007). Improving Municipal Solid Waste Management in India: A Sourcebook for Policymakers and Practitioners. Washington DC: The World Bank. https://doi.org/10.1596/978-0-8213-7361-3

Zohoori, M., \& Ghani, A. (2017). Municipal Solid Waste Management Challenges and Problems for Cities in Low-Income and Developing Countries. International Journal of Science and Engineering Applications, 6, 39-48.

https://doi.org/10.7753/IJSEA0602.1002

http://www.ijsea.com/archive/volume6/issue2/IJSEA06021002.pdf 